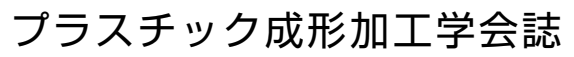

目次

\section{特集 ガスバリア}

\section{栄䫓言}

○プラスチックはバリア材料と言えるのか＼cjkstart永井一清

49

\section{解 説}

○ボイル・レトルト用ハイガスバリアナイロンフィルムの開発＼cjkstart岡部貴史／西本彰二 50

○タイヤ用ガスバリア材料技術＼cjkstart原＼cjkstart祐一

透明バリアフィルムと医療医薬品包装材＼cjkstart黒瀬圭史

54

○有機／無機積層構造を用いた透明バリアフィルム＼cjkstart鈴木信也

\section{技術䠟告}

OLIB 用セルロースナノファイバー複合化ポリエチレンセパレータの開発

石黒 亮 /中村 諭 /串崎義幸 /吉岡まり子 /向井孝志 / 境 哲男

\section{猃 文}

○樹脂一金属接合射出成形品の接合強さに与える成形条件の影響 


\section{Seikei-Kakou}

\section{Special Issue on Gas Barrier}

\section{Foreword}

OIs a Plastic Product a Barrier Material ? Nagai, Kazukiyo

\section{Technical Notes}

ODevelopment of the High Gas Barrier Nylon Film for Boil and Retort

Okabe, Takashi/Nishimoto, Shoji

Gas Impermeable Material Technology for Tires

Hara, Yuichi

Transparent Barrier Films for Medical and Pharmaceutical Packaging Materials

Kurose, Yoshifumi 57

\section{Technical Report}

Development of the Polyethylene and Cellulose Nanofiber Composites Separator Film for LIB Ishiguro, Ryo / Nakamura, Satoru /Kushizaki, Yoshiyuki/Yoshioka, Mariko /

\section{Original Paper}

Onfluence of Molding Conditions on Joining Strength of Injection Molded Parts Joined with Metal and Resin

Seto, Masahiro / Asami, Yoshihiro / Itakura, Masahiko /Tanaka, Hiroaki /Yamabe, Masashi 